\title{
Accounting for the Mexican banking crisis
}

\author{
Klaus Desmet*
}

Departamento de Economía, Universidad Carlos III de Madrid, 28903 Getafe, Madrid, Spain

\begin{abstract}
The Mexican banking crisis of 1994-1995 has widely been interpreted as the victim of the balance-of-payments crisis, rather than its cause. After all, Mexican banks had been enjoying high capitalization ratios, deemed to be more than sufficient to deal with the increased risk of non-performing loans. This paper, however, suggests that to a large extent Mexican accounting practices - rather than sound principles - were responsible for the apparent good health of the banking system. The role of banks in causing the Mexican crisis may therefore have been greater than previously thought.
\end{abstract}

JEL classifications: F30; G21; O54; O16

Keywords: Banking crisis; Mexico

\section{Introduction}

In 1994-1995 Mexico went through its worst crisis since the Great Depression. A speculative attack against the peso caused the exchange rate to devalue by more than $50 \%$; inflation and interest rates sky-rocketed; and the economy went into a severe recession. At the same time, non-performing loans caused trouble in the banking sector, and several banks had to be bailed out by the government.

\footnotetext{
${ }^{*}$ Tel.: + 34-91-624-9845; fax: +34-91-624-9875.

E-mail address: desmet@eco.uc3m.es (K. Desmet).
} 
The causes of this crisis have been analyzed in detail. The standard explanation has pointed to the overvalued exchange rate as the main culprit (Dornbusch and Werner, 1994; Krugman, 1995; OECD, 1995; Gil-Díaz and Carstens, 1996). The argument is not hard to follow. A continued positive inflation differential with the United States, combined with a policy of keeping the exchange rate pegged to the US dollar, led to an increasing overvaluation of the currency, causing lackluster growth and a widening trade deficit. In those circumstances, the exchange rate must sooner or later devalue, either through action taken by the Banco de México, or forced by a speculative attack. This is what happened in December 1994; as the peso came under attack and was brought down, interest rates and inflationary expectations went up, causing default problems in the banking sector.

Other studies have complemented this view by emphasizing the role of selffulfilling expectations (Krugman, 1995; Calvo and Mendoza, 1996; Cole and Kehoe, 1996; Sachs et al., 1996). As the volume of central bank reserves gradually dropped below that of short-term debt during 1994, investors became less upbeat about Mexico's future. This shift in mood made them unwilling to further roll over the debt, thus triggering the balance-of-payments crisis.

If the last word seems to have been said on this crisis, why the need for yet another paper on the subject? Because, as will be argued, the role of the banking system in contributing to the crisis has generally been underestimated. Notable exceptions are Wilson et al. (2000), who look at the effect of the devaluation on the banks' assets, and Calvo and Mendoza (1996), who argue that expectations of a future bailout of the banking sector may have set off the crisis. Nevertheless, there has been a relative lack of interest in the role of Mexican banks in the 1994-1995 crisis. This may be due to the fact that on the surface, banks appeared to be in good health. Although the volume of non-performing loans had been increasing, the banking system's capitalization ratio stood at a sturdy $9.81 \%$ in December 1994, well above the $8 \%$ set forth by the Basle recommendations. In that case, if the banks ran into trouble, as they did, it must surely have been because of the balance-of-payments crisis, rather than the other way around.

However, a closer look at the peculiarities of Mexican accounting rules suggests that capitalization ratios may in reality have been much lower. For instance, it was standard practice to classify as non-performing only that part of a loan which had not been serviced on time, rather than the entire loan, as would be the case under US or European accounting principles. It thus follows that the volume of non-performing loans was grossly understated, causing observed capitalization ratios to be upward biased. This paper therefore suggests that the banking system was in worse health than at first appeared; its role in contributing to the crisis may thus have been greater than previously thought.

The rest of the paper is organized in the following way. Section 2 analyzes the banking sector, using balance sheet data of individual banks; Section 3 takes a closer look at Mexican accounting; Section 4 analyzes the relation between the banking and the balance-of-payments crises; and Section 5 makes some concluding remarks. 


\section{Diagnosing the Mexican banking sector}

The Mexican banking system was clearly deteriorating from 1992 onwards, as reflected by the increasing volume of non-performing loans. This, however, did not create particular cause for concern to the Banco de México, since it believed the necessary regulatory measures had been taken to safeguard the viability of the banking system. This view is reflected in reports of the Banco de México:

'The existing frameworks for capitalization requirements, rating of credit portfolios, and creation of preventive reserves have helped to lessen the risks stemming from the deterioration of the ratio of non-performing loans'. (Banco de México [1994a], The Mexican Economy 1994, pages 91-93)

Guillermo Ortiz, at the time Minister of Finance, argued along the same lines:

'As a proportion of the total portfolio, non-performing loans have increased from $1.27 \%$ in 1988 to $7.54 \%$ in September 1993. However, the loan-loss reserves as a proportion of non-performing loans increased from 11 to $42 \%$ [over the same period].' (Ortiz, 1994, op. cit., page 209)

After giving some background information on the liberalization of the banking system, individual balance sheets will be analyzed in order to illustrate the banking sector's increased vulnerability.

\subsection{The deregulation of the banking system ${ }^{1}$}

The Mexican financial system was nationalized on 1 September 1982, during the previous balance-of-payments crisis. At the same time, exchange and interest rate controls were re-imposed. A first step to financial liberalization was taken in 1988 with the creation of banker's acceptances, short-term letters of credit issued by companies and guaranteed by commercial banks. It was the first time that interest rates on money market instruments were allowed to be set freely. Moreover, reserve requirements on banker's acceptances were lowered to 30\%. Further progress was made in 1989 with the lifting of interest rate ceilings on all deposits and securities held by banks and the elimination of mandatory credit allocation. Cross-ownership restrictions, limiting the formation of financial groups, were eased in 1989.

Financial liberalization was further completed by the privatization of commercial banks, initiated by the approval of the Credit Institutions Law of June 1990. Between June 1991 and July 1992, 18 banks were sold at extraordinarily high average price-to-book ratios. The Credit Institutions Law also paved the way for a universal banking system that for the first time allowed banks to provide mutual fund management, foreign exchange dealing and warehousing of derivative instruments. The financial conglomerates that emerged from the concentration of those activities became known as grupos financieros. At the time of the crisis the banking

\footnotetext{
${ }^{1}$ For an overview, see Aspe (1993) and Ortiz (1994).
} 
system was composed of nine public development banks and 32 private banks. ${ }^{2}$ However, the domestic lending market was dominated by three banks which accounted for nearly half of the assets of the consolidated banking system. ${ }^{3}$ Following the Basle recommendations, bank capital standards based on credit risk were adopted between 1991 and 1993.

Overall, deregulation of the banking sector and of financial markets increased capital inflows and gave banks easier access to credit, creating a rapid credit expansion. Credit outstanding to the private sector increased in percentage of GDP from $20 \%$ in 1989 to $55.3 \%$ in 1994 . $^{4}$ This credit was not always sound due to the inexperience of the banking sector and excessive risk taking. As is well known, implicit or explicit deposit insurance by the government may cause moral hazard, whereby banks count on being bailed out when things go wrong, thus encouraging them to invest in overly risky projects (McKinnon and Pill, 1996). Furthermore, the high real interest rates created a problem of adverse selection (Mishkin, 1990, 1992). Since successful firms had access to lower interest rates on the international capital market, peso loans by Mexican banks were of an implicitly lower quality.

\subsection{The increasing vulnerability of the banking system}

\subsubsection{The main problem: non-performing loans}

As can be seen from Fig. 1, the share of non-performing loans of the banking system increased from a level close to $0 \%$ in 1990 to approximately $6 \%$ in the beginning of 1994; it followed this upward trend during 1994, reaching $8 \%$ by November 1994. Before concluding, however, that the banking crisis was mainly due to non-performing loans, other potential loss sources must be analyzed more closely.

All deposits, including the ones in the inter-banking market, were subject to variable interest rates (mostly indexed to the 4-week Cetes rate). The same was true for assets. Loan rates were typically set by adding a specific premium to the so-called Tasa de Interés Interbancario de Equilibrio (TIIE). It was thus easy to ensure a positive spread, so that the trouble in the banking sector did not originate from a time lag between the adjustment of loan and deposit rates. This is not to say that there was no maturity mismatch. Though on the surface both loans and deposits had short maturities, it was common for short-term loans to finance long-term projects; there was thus an implicit understanding that those short-term loans would be automatically rolled over, converting them in de facto long-term loans. When the crisis - and the credit crunch - hit, banks became unable to continue this practice, leading to a sharp increase in non-performing loans.

\footnotetext{
${ }^{2}$ Publicly owned development banks provide priority financing to the export sector, local government infrastructure projects and small- and medium-size enterprises (OECD, 1995, op.cit., pages 27-28).

${ }^{3}$ These banks were Banamex, Bancomer and Serfin (Comisión Nacional Bancaria y de Valores, 1996).

${ }^{4}$ OECD (1995), op.cit., page 36, quoting figures from the Banco de Mxico.
} 


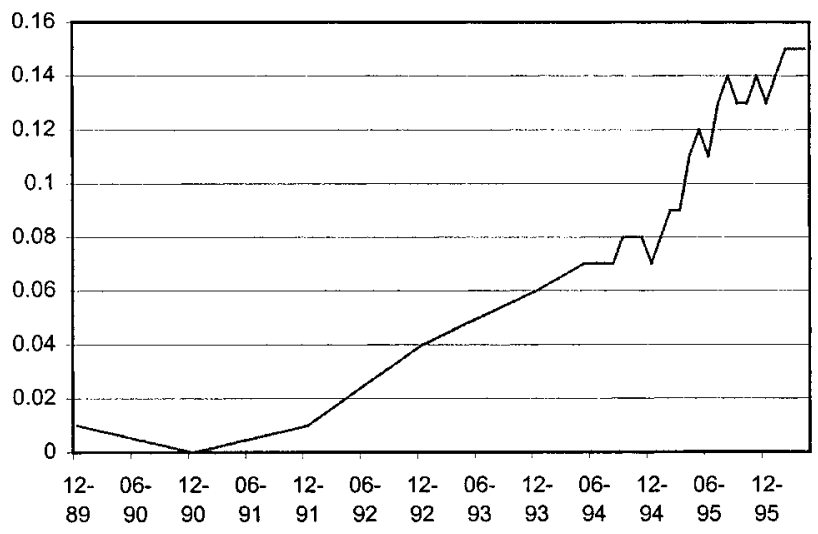

Source: Banco de México

Fig. 1. Non-performing loans as a fraction of total loans.

It remains to be seen whether assets other than loans - bonds and stocks may have been responsible for the losses suffered by the banking system. In most countries bonds have maturities of up to at least 10 years. The longer the maturity, the more bond prices get negatively affected by rising interest rates. This drop in market value of bonds must be reflected in the banks' balance sheets. However, the Mexican bond market was made up of money market discount bonds with a maximum maturity of 1 year. Depreciations of bond positions denominated in pesos were therefore hardly noticeable in 1994. Also stocks, which made up at most $10 \%$ of the banking system's assets, did not cause any major upheaval. In the period from December 1993 to December 1994 the stock market only fell by $8.68 \%$, and recovered to its pre-crisis level by the end of 1995 .

This leaves us with exchange rate risk as the last possible source of trouble. Since the net foreign exchange position of Mexican banks was limited to $15 \%$ of net capital, this was not directly a major issue. Nevertheless, the devaluation of the peso did indirectly worsen the non-performing loan problem. Since many firms were partly indebted in dollars, their situation degraded after the fall of the peso, making it more difficult to service their loans, including those denominated in pesos.

The banking sector's troubles were therefore mainly due to non-performing loans with other potential loss sources playing only a secondary role.

\subsection{Non-performing loans: a disaggregated analysis}

As shown by Fig. 1, the fraction of non-performing loans increased steadily since the beginning of 1992. On a disaggregated level the picture looked even more worrisome. By November 1994, approximately $10 \%$ of the banking system had a 


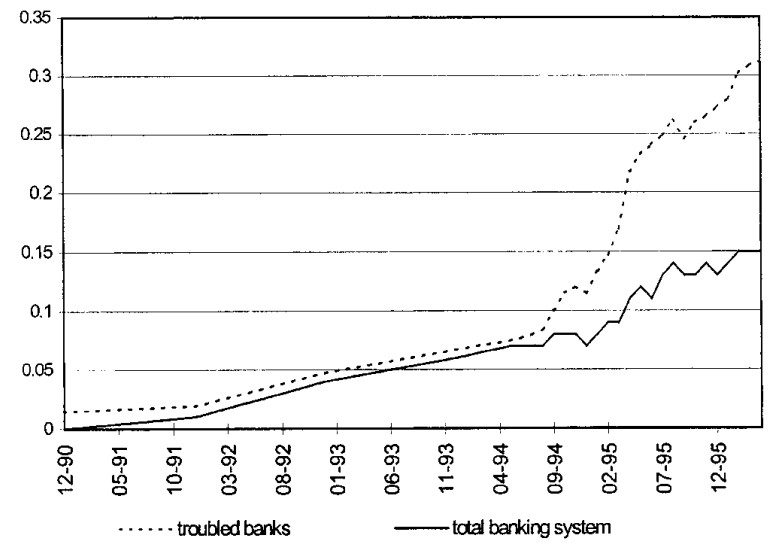

Source: Banco de México. Troubled banks include Inverlat, Bital, Banpais, Unión, Probursa, Cremi and Centro

Fig. 2. Non-performing loans as a fraction of total loans (troubled banks and total banking system).

share of $10 \%$ or more of non-performing loans (Fig. 2). ${ }^{5}$ Banco Unión, representing close to $2 \%$ of the banking system, even reached a level of $50 \%$ of non-performing loans. In September 1994 the National Banking Commission intervened in Banco Unión and Banca Cremi because of fraudulent practices, and granted them financial support through the Bank Fund for the Protection of Savings (FOBAPROA). It is worth noting that Banco Unión was insolvent, but the government preferred a bail-out to bankruptcy. In 1995 FOBAPROA intervened in six more banks, including Banpaís, Banco del Centro and Banco Inverlat.

Given the very different performance of individual banks, it is revealing to contrast the loan portfolios of the troubled banks to those of the banking system as a whole. By doing so, we get additional insights about what caused the crisis. In comparison to the overall commercial banking system, the troubled banks had a relatively bigger fraction of loans to the private sector than to households. Whereas loans to the private sector and to households made up 54 and $42 \%$ of the commercial banks' loan portfolio in 1994-1995, for the troubled banks these figures were 59 and $38 \%$, respectively. Maybe more importantly, the troubled banks saw a relatively greater increase in non-performing loans to the private sector (Figs. 3 and 4).

\footnotetext{
${ }^{5}$ These banks were Bital, Banco Mercantil del Norte, Banco Unión and Banca Cremi, which in terms of assets represented $8.81 \%$ of the total banking sector or $11.3 \%$ of the commercial banking sector in November 1994.
} 


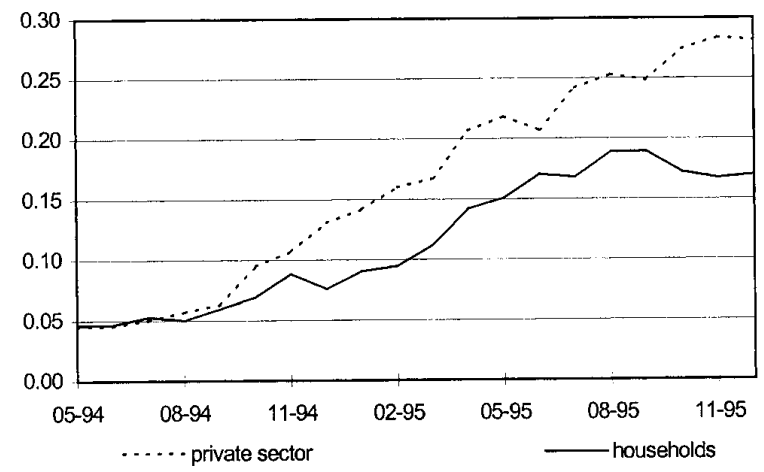

Source: Banco de Mexico. The fraction of non-performing loans to a sector $x$ is defined as: (nonperforming loans to sector $x) /($ total loans to all sectors)

Fig. 3. Non-performing loans to households and private sector (troubled banks).

The rise in non-performing loans to firms may thus have been at the basis of the banking system's increasing vulnerability. It should be noted that most of these loans were short-term. ${ }^{6}$ The default on loans by firms may have been due to a variety of reasons. First, business and bank failures tended to reinforce each other. Second, as mentioned before, adverse selection left Mexican banks with bad credit, since the better firms were able to tap the international credit market at cheaper interest rates. Third, some Mexican bank directors were quite lavish in handing out loans to companies they owned themselves.

This is not to say that households did not default on their debt. Actually, bad loans to households were initially at an even higher level than non-performing loans to businesses. ${ }^{7}$ However, the relative increase in bad loans to businesses was more pronounced. ${ }^{8}$ Another interesting observation is that consumption loans which form part of loans to households - made up a bare $7 \%$ of the banking system's loan portfolio. The widely spread idea that credit card debt was at the origin of the banking crisis should thus be tempered.

\footnotetext{
${ }^{6}$ The particular type of loan is a short-term loan called 'Crédito en cuenta corriente'.

${ }^{7}$ Note, however, that the bad loans problem to the households - especially in the case of housing loans - may be underestimated because of Mexican accounting roles. We will return to this issue subsequently.

${ }^{8}$ This may be partly due to a government program to bail-out small debtors $(A D E)$. However, the increase in bad loans to businesses occurred well before the $A D E$ program was put in place in September 1995.
} 


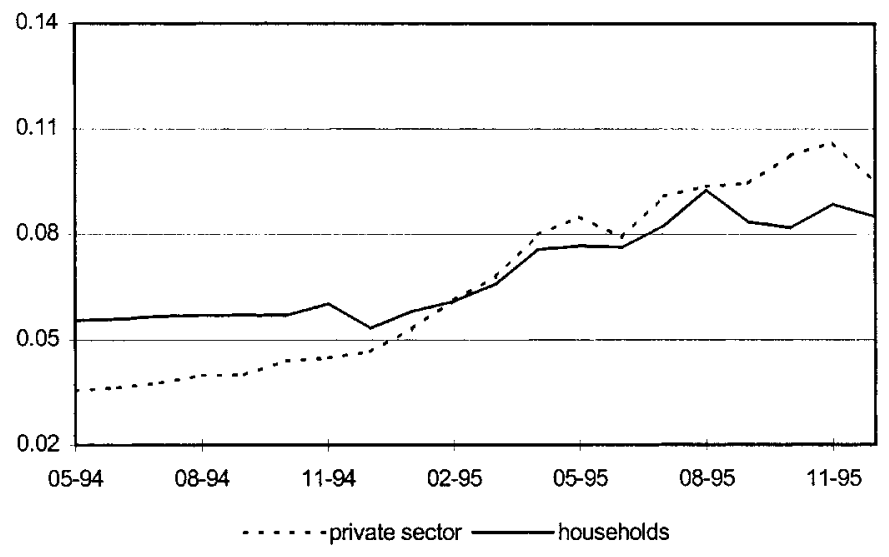

Source: Banco de Mexico. The fraction of non-performing loans to a sector $x$ is defined as: (nonperforming loans to sector $x$ )/(total loans to all sectors)

Fig. 4. Non-performing loans to households and private sector (all commercial banks).

\subsection{Loan-loss reserves and capitalization ratios}

The figures on non-performing loans should be analyzed relative to the precautionary measures - loan-loss reserves and capitalization ratios - taken by the banks to insure themselves against the risks deriving from the possible default of debtors. As mentioned before, although non-performing loans had clearly been rising since 1992, it was widely thought that banks had taken sufficient measures to deal adequately with the increased risk.

Before turning to the graphs, the role of loan-loss reserves and capitalization ratios must be explained. When a bank takes on more risky loans, it is obliged to increase its loan-loss reserves as a preventive measure in case the loans go awry. As a complementary cautionary requirement the bank's capitalization ratio - net capital as a share of risky assets - is not supposed to fall below a certain threshold.

Fig. 5 represents the loan-loss reserves as a fraction of non-performing loans. As can be seen, their level remained fairly stable until August 1994 when the banking crisis started in earnest. Fig. 6 gives an even rosier outlook: as the non-performing loan problem steadily worsened from 1992 onwards, not only did the capitalization ratio hold up pace, it actually increased to a healthy $9-10 \%$, well above the $8 \%$ officially recommended by Basle (Dewatripont and Tirole, 1994). ${ }^{9}$ Based on these figures, the Mexican banking system seemed on the surface well prepared to deal with the lingering debt default problem. 


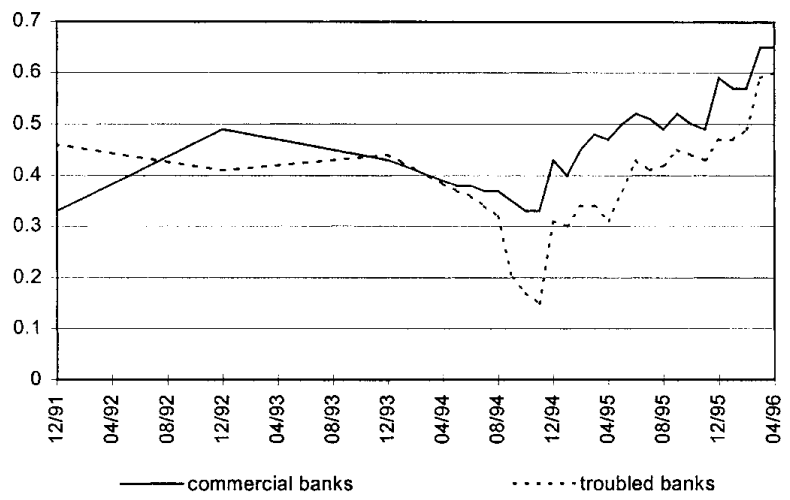

Source: Banco de México. The troubled banks include Banco Unión, Banca Cremi, Banpais, Banco del Centro and Bital.

Fig. 5. Loan-loss reserves as a fraction of non-performing loans.

\section{Accounting for Mexican accounting}

\subsection{Peculiar features of Mexican accounting}

Although Mexican banks seemed adequately insured against default risks, much of the problem was hidden behind the peculiarities of Mexican accounting practices at the time. Since those were quite different from generally accepted accounting principles (GAAP), comparing Mexican loan-loss reserves and capitalization ratios to internationally accepted standards makes little sense. Before making an attempt to correct for some of these differences, we give a brief overview of Mexican accounting rules as they applied to the specific problem of non-performing loans.

Mexican law required to classify as non-performing only that fraction of the loan (or of the interest payment) which was due and had not been paid back, contrary to international accounting practices, which oblige the total loan to be considered as non-performing as soon as part of it has not been repaid. ${ }^{10}$ This meant that under the Mexican system the volume of non-performing loans tended to appear with a lag. This problem was particularly acute in the case of housing loans, with long maturities of up to 30 years and with the payback of the principal typically backlogged.

\footnotetext{
${ }^{9}$ Note that the data in Fig. 6 go until March 1994. No further data are available for comparison, since the data provided by the Banco de México for the banking system only concern banks not affected by the government bailout.

${ }^{10}$ Williams (1995), op.cit., pages 7.03-7.12 and 20.03-20.08.
} 


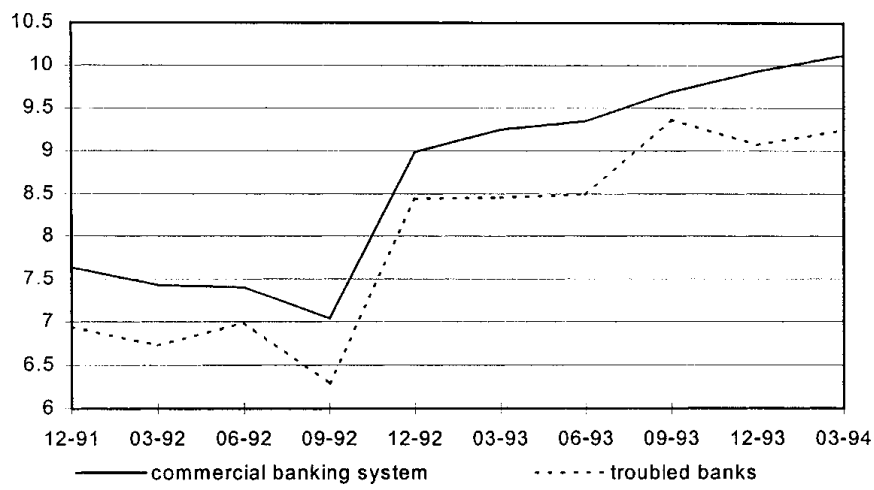

Source: Banco de México (troubled banks include Unión, Cremi, Probursa, Bital, Centro and Banpaís)

Fig. 6. Capitalization ratios.

For other types of loans one would think this problem to have been less severe, given the relatively short maturity of the banks' loan portfolio. ${ }^{11}$ However, as argued above, it was common in Mexico to roll over loans in case of inability to pay back. ${ }^{12}$ By doing so, banks were able to mask the riskiness of those loans, and thus limit reserve provisions.

Another problematic feature of the Mexican system was to be found in the risk classification of loans, which was largely left up to the discretion of the individual bank. Maybe surprisingly, this subjective categorization may have encouraged banks to overstate the volume of non-performing loans by not writing off bad loans fast enough. As in other countries, Mexican law requires non-performing loans to be removed from the balance sheet as soon as the bank has a strong suspicion that the debtor will be unable to comply in the future. Since writing off loans forces banks to recapitalize, there existed a clear incentive to slow down this procedure.

All of the above practices tended to inflate capitalization ratios, relative to what they would have been following international accounting standards. The first two practices - considering as non-performing only that part of the loans which has not been reimbursed and rolling over short-term loans - allowed banks to dissimulate the true riskiness of their assets. By reducing the apparent volume of risky loans, they artificially inflated capitalization ratios. Though the last practice

\footnotetext{
${ }^{11}$ OECD (1995), op.cit., page 37.

${ }^{12}$ In case of inability to pay back, the bank could of course claim the collateral. However, due to a lack of regulation, the same collateral was often used for different loans.
} 
Table 1

Capitalization ratio in function of assets being written off $(\%)$

\begin{tabular}{ll}
\hline Assets to be written off $(\%)$ & Capitalization ratio $(\%)$ \\
\hline 0 & 9.8 \\
1 & 8.2 \\
2 & 6.5 \\
3 & 4.7 \\
4 & 2.9 \\
\hline
\end{tabular}

- not writing off loans fast enough - raised the volume of non-performing loans, it had the same effect of increasing capitalization ratios. Indeed, if certain loans had been written off, the volume of risky assets (the denominator of capitalization ratios) and preventive reserves (the numerator of capitalization ratios) ${ }^{13}$ would have gone down by the same amount, thus reducing capitalization ratios; by not writing off those loans, capitalization ratios therefore appeared higher than they should have. A particular example of this possibility is worked out in the next section. In the light of these accounting practices, it is obvious that the capitalization ratios and the loan-loss reserves of Figs. 5 and 6 are hard to interpret.

\subsection{A simple back-of-the-envelope correction}

In this section we attempt to make a crude back-of-the-envelope calculation of what the capitalization ratio would have been, had international accounting standards applied. In doing so, we focus on the specific problem of not writing off certain assets. On the one hand, some of the non-performing loans should have been removed from the balance sheets, but were not. On the other hand, some of the loans classified as 'good' were in reality non-performing, and part of those should also have been removed.

It is of course hard to know the share of assets to which this problem applied. In the example given below it is somewhat arbitrarily assumed that $2 \%$ of all assets should have been written off under GAAP. (In Table 1 we carry out the same exercise for different shares.) As the baseline we take the economic figures of the Mexican economy in December 1994:

Non-performing loans / total assets $=0.05$

Capitalization ratio $=$ capital $/$ risky assets $=0.0981$

Capital asset ratio $=$ capital $/$ total assets $=0.055$

\footnotetext{
${ }^{13}$ Loan-loss (or preventive) reserves are part of net capital, the numerator of the capitalization ratio.
} 
Combining Eqs. (2) and (3), the capitalization ratio can easily be re-written as:

Capitalization ratio $=[0.055 \times$ total assets $] /[(0.0981) \times$ total assets $]$

Writing off loans can be understood in two steps. First, the reserve provisions for the loans are raised to $100 \%$. This does not affect capital though, since higher provisioning increases loan-loss reserves (part of capital) and decreases profits (also part of capital). Second, the actual writing off occurs by removing the loans from the asset side and by withdrawing the preventive reserves from the liability side. If $2 \%$ of all assets had been written off, both the numerator and the denominator of the capitalization ratio in Eq. (4) would have decreased by $0.02 \times$ total assets. $^{14}$ This would have corresponded to a drop in the capitalization ratio from 9.8 to $6.5 \%$, an unacceptably low figure according to the Basle recommendations.

As to be expected, the greater the share of assets being written off, the bigger the effect on the capitalization ratio (Table 1). Though these calculations are far from exact, they do suggest that changes in accounting practices may have a significant effect on the capitalization ratio.

\section{The interaction of the banking and the balance-of-payments crises}

After having made clear that the banking system's health was clearly deteriorating before the December 1994 peso devaluation, it is necessary to sketch a broader picture of the Mexican economy in order to analyze the potential links between the banking crisis and the balance-of-payments crisis. It will be claimed that the balance-of-payments crisis developed parallel to the banking crisis, and that the Banco de México was limited in the defense of its exchange rate policy because of the vulnerable banking system. Furthermore, it will be suggested that the weak banking system was partly responsible for the intensity of the economic crisis.

\subsection{The situation before December 1994}

Real interest rates rose following financial liberalization, but later started falling from approximately 7\% in March 1993 to 3\% in February 1994. Nominal interest rates (Cetes 28-day rate) came down from $19.39 \%$ in October 1992 to $9.45 \%$ in February 1994. Inflation measured by the CPI was brought under control reaching single digits for the first time in 1993 and further decreasing to 6.7\% in September 1994. Compared to international figures nominal and real interest rates were therefore not high in the beginning of 1994 (OECD, 1995). Consequently, the

\footnotetext{
${ }^{14}$ This calculation is approximate, since the denominator (risky assets) is in reality a relatively complex weighted sum of assets (where the weight increases with risk).
} 
growing problem of non-performing loans was initially not caused by rising interest rates.

As often occurs in financial crises, the use of the currency as a nominal anchor steadily appreciated the real value of the Mexican peso. This eroded Mexico's international competitiveness, as reflected by its widening current account deficit, which reached $8 \%$ of GDP in 1994 . Partly due to the misalignment of the exchange rate, growth remained unsatisfactorily low with an average of 3\% between 1990 and 1994.

The substantial current account deficit was also related to low domestic savings and important foreign capital inflows. Financial deregulation did not generate additional private savings. Although total savings remained stable at a level of approximately $22-25 \%$ of GDP, its composition changed: private savings went down, but were compensated by strong public sector savings until the beginning of 1994. Because of Mexico's success in getting inflation down, important capital inflows (almost two-thirds of which was portfolio investment) were attracted between 1991 and March 1994. The policy of complete sterilization of capital inflows by the Banco de México prevented a huge increase in the money supply. Base money grew at a constant rate which slightly increased during 1994 . The sterilization policy contributed to keeping inflationary expectations down.

\subsection{The buildup of the balance-of-payments and the banking crisis}

The situation worsened in March 1994 with the assassination of presidential candidate Colosio followed by a first speculative attack against the peso. Nominal and real interest rates rose sharply in the short term to later stabilize at a level of approximately $5 \%$ points higher than in the beginning of 1994. At this point, the balance-of-payments crisis and the banking crisis became virtually unavoidable. Two policy options were now open to the Banco de México. First, if interest rates were allowed to rise to protect the exchange rate, the financial system would be further weakened because of an increase in non-performing loans, making a fiscal bail-out more likely. As will be explained, a rise in interest rates causes an increased amortization of loans, putting pressure on debtors and thus adding to the already high pool of non-performing loans. Second, if the government tried to keep interest rates in check in order to save the banking system, it would further fuel (bad) credit to the private sector. The low interest rates would weaken the position of the peso, increasing the probability of a speculative attack against the currency and making the sustainability of the exchange rate regime more difficult. Aware of the problems of the banking sector, the Banco de México chose for the second option. ${ }^{15}$ Through its policy of sterilization the Mexican central bank limited the increase of interest rates, though they did rise somewhat because of higher US interest rates and an increased probability of devaluation.

\footnotetext{
${ }^{15}$ See Banco de México (1994b), Report on Monetary Policy (May 1994) and OECD (1995), op.cit., page 38 .
} 
In spite of the only limited rise in interest rates, the situation of the banking system worsened further and the government intervened to bail out two banks in September 1994. In November 1994 the outstanding amount of Tesobonos, a short-term bond indexed to the dollar, exceeded the dollar reserves of the Banco de México. The impossibility to refinance triggered the balance-of-payments crisis in December 1994. Intervention efforts could not be kept up to defend a speculative attack against the peso on 21 December, and the peso was allowed to float. The high probability of default by the Mexican government on Tesobonos sent interest rates upward. The Cetes rate reached 74.75\% in April 1995, whereas real interest rates rose to $45.35 \%$. Inflation grew steadily, reaching $52 \% /$ year in December 1995. This partly reflected the government's need to generate inflation revenues in order to compensate for interest rate payments on foregone foreign reserves.

The role of the banking system in the balance-of-payments crisis may be summarized in the following way. The vulnerability of the banks, which had been built up over several years, made a balance-of-payments and banking crisis virtually unavoidable. In order to protect the banking system, the Banco de México chose not to raise interest rates too much, thus making a balance-of-payments crisis highly probable. The alternative of defending the peso in a more aggressive way by raising interest rates would merely have worsened the banking problems. This would have fueled inflationary expectations because of an increased probability of a government bailout of the banking system, thus precipitating a balance-of-payments crisis. A stronger banking sector would have allowed the Banco de México to defend the currency. This is not to say that rising interest rates would have been a credible policy to sustain the peso and avoid the December 1994 crisis, but it remains true that this policy option was simply not available. Furthermore, higher interest rates might at least have limited the devaluation of the peso.

\subsection{The rise in interest rates worsened the banking crisis}

The devaluation of the peso in December 1994 created a significant increase in the volume of non-performing loans. Since part of the loans were denominated in foreign currency, the drop of the peso clearly increased their default risk. Furthermore, the devaluation raised both nominal and real interest rates, reflecting higher inflationary expectations and a higher perceived risk of further devaluations. The increase in the real interest rates led to a higher default risk on variable interest loans (and on rolled-over fixed interest loans), ${ }^{16}$ since firms' profits presumably did not grow at the same rate as their refinancing costs.

But also the rise in nominal interest rates increased the default risk, because of a reduction in the duration of loans. Intuitively, it is easy to understand that when inflation and nominal interest rates go up, the initial interest payments become more important and the final principal payment less important. In other words, an

\footnotetext{
${ }^{16}$ As argued before, short-term fixed interest loans which are rolled over can be thought of as de facto.
} 
increase in nominal interest rates obliges the debtor to amortize his loan faster. This is equivalent to the duration of the loan decreasing. Duration is therefore different from maturity, and may be considered a measure of the average life of a debt instrument on a present value basis (Hopewell and Kaufman, 1973). The effect of rising interest rates on the duration of debt contracts is illustrated in Box 1.

The balance-of-payments crisis therefore worsened the banking crisis not only because of rising real interest rates, but also because of increasing nominal interest rates. This problem was partially dealt with by restructuring loans in Unidades de Inversión (UDIs), a unit of account with constant real value. This restructuring program changed variable interest loans into fixed-rate indexed loans, thus taking off pressure to pay back the loan at an increased rate.

Box 1. The duration of loans

Duration of debt contract: The Macaulay duration measure of a debt contract may be considered as the average life time (in years) of the debt instrument on a present value basis. The Macaulay duration formula is given by:

$$
\frac{\sum_{t=1}^{n} \frac{C_{t}(t)}{(1+R)^{t}}}{\sum_{t=1}^{n} \frac{C_{t}}{(1+R)^{t}}}
$$

where

- $C=$ interest or principal payment;

- $(t)=$ length of time to the interest or principal payment;

- $n=$ length of time to maturity; and

- $R$ = yield-to-maturity.

The Macaulay-duration is always shorter than the maturity of the loan except for zero-coupon loans where they are equal.

Shortening of duration and rising nominal interest rates:

Rising nominal interest rates because of increasing inflation forces debtors to amortize their loan faster in real terms. This increased weight of real payments at the beginning of the debt contract is reflected in a reduced duration. An example will illustrate this phenomenon (Fig. 7). Consider a 20-year housing loan with the following conditions: quarterly interest payments (CPP rate $+5 \%$ annually) and quarterly repayment of principal in a flat fashion. The interest payment and the yield of the loan are supposed to be the same. Stationary expectations are assumed, so that expected future interest rates are the same as present interest rates. When nominal interest rates go up as during 1994, duration reduces. 


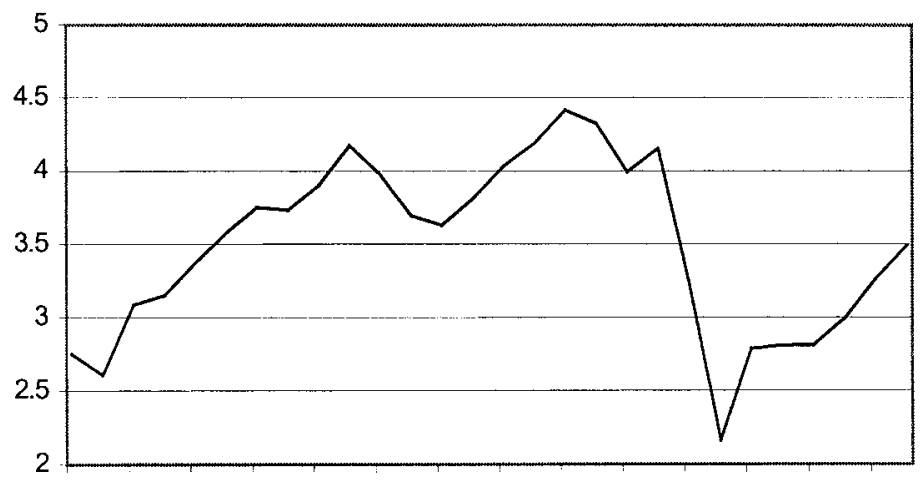

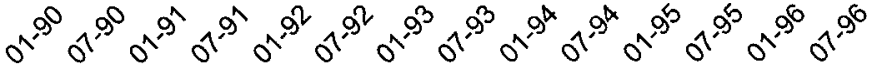

Fig. 7. Duration of a 20-year housing loan.

\subsection{The worsening of the banking crisis increased interest rates}

Not only did rising interest rates deepen the banking crisis, the worsening crisis also raised interest rates further because of the bailout of the banking system. A loan restructuring plan and a special program designed to help small debtors had an additional negative effect on the fiscal deficit, thus causing higher expected inflation and nominal interest rates. Also real interest continued to increase because of the perceived currency risk.

We were thus in the presence of a self-reinforcing mechanism, where the worsening banking crisis led to rising interest rates, and where rising interest rates led to a further worsening of the banking crisis. Had the banking system been healthier to start with, this self-reinforcing process would have been weaker, thus causing less damage to the economy.

\section{Concluding remarks}

In spite of apparently high capitalization ratios, this paper argues that the health of Mexican banks had been worsening since 1992. Not only did the volume of non-performing loans steadily increase, capitalization ratios were probably substantially lower than the numbers revealed. Indeed, the seemingly satisfactory capitalization ratios had much to do with the peculiarities of the Mexican accounting system. Unlike the emphasis of most economists on the overvalued exchange rate, this paper therefore suggests that the banking sector is crucial in understanding the Mexican crisis of 1994-1995. It also shows the importance of analyzing country- 
specific accounting practices, before simply comparing certain numbers to internationally accepted standards. As a final note, it is worth mentioning that Mexico is currently adjusting its accounting system to GAAP.

\section{Acknowledgements}

The author wishes to thank the hospitality of the Banco de México, where a large part of this research was conducted. The opinions expressed in this paper, however, are the sole responsibility of the author, and do not in any way reflect those of the Banco de México. Further thanks to Thomas Mann, who collaborated on part of this project, Ronald McKinnon, Chris Sleet, an anonymous referee and seminar participants at Stanford University.

\section{References}

Aspe, P., 1993. Economic Transformation - The Mexican Way. MIT Press, Cambridge, Mass.

Banco de México 1994a. The Mexican Economy, various issues.

Banco de México, 1994b. Report on Monetary Policy. May.

Calvo, G.A., Mendoza, E.G., 1996. Mexico's balance-of-payment crisis: a chronicle of a death foretold. J. Int. Econ. 41, 235-264.

Cole, H.L., Kehoe, T.J., 1996. A self-fulfilling model of Mexico's 1994-1995 debt crisis. J. Int. Econ. 41, 309-330.

Comisión Nacional Bancaria y de Valores, 1996. Boletín estadístico de banca múltiple, various issues.

Dewatripont, M., Tirole, J., 1994. The Prudential Regulation of Banks. MIT Press, Cambridge, Mass.

Dornbusch, R., Werner A., 1994. Mexico: Stabilization, Reform, and No Growth. Brookings Papers of Economic Activity 253-315.

Gil-Díaz, F., Carstens A., 1996. Some hypotheses related to the Mexican 1994-95 crisis. Banco de México Working Paper No. 9601.

Hopewell, M.H., Kaufman, G.G., 1973. Bond price volatility and term to maturity: a generalized respecification. Am. Econ. Rev. 63, 749-753.

Krugman, P., 1995. Dutch Tulips and Emerging Markets. Foreign Affairs. July/August.

McKinnon, R.I., Pill, H., 1996. Credible liberalizations \& international capital flows: the overborrowing syndrome. In: Ito, T., Krueger, A.O. (Eds.), Financial Deregulation and Integration in East Asia. Chicago University Press, Chicago.

Mishkin, F., 1990. Asymmetric information and financial crises: a historical perspective. NBER Working Paper No. 3400.

Mishkin, F., 1992. Anatomy of a financial crisis. J. Evol. Econ. 2, 115-130.

OECD, 1995. Economic Survey Mexico. OECD, Paris.

Ortiz, G., 1994. La reforma financiera y la desincorporación bancaria. Fondo de Cultura Económica, México.

Sachs, J., Tornell, A., Velasco, A., 1996. The Mexican peso crisis: sudden death or death foretold. J. Int. Econ. 41, 265-283.

Williams, J.R., 1995. GAAP Guide. San Diego.

Wilson, B., Saunders, A., Caprio, G., 2000. Mexico's financial sector crisis: propagative links to devaluation. Econ. J. 110, 292-308. 